\title{
FLOAT-SINK SEPARATION OF CONSTRUCTION AND DEMOLITION WASTE FINES
}

\section{Erik Marklund *, Lale Andreas and Anders Lagerkvist}

Waste science \& technology, Luleå University of Technology, Sweden

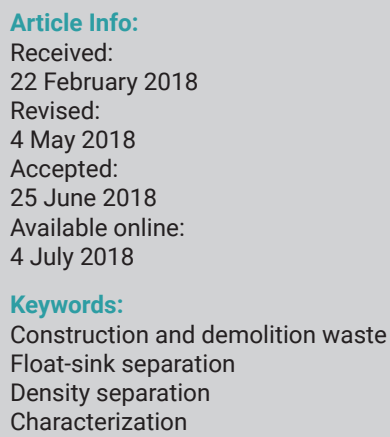

\begin{abstract}
Landfilling and waste incineration are two major waste management options. However, due to their carbon content, some wastes may be unsuitable for these systems. Therefore, methods capable of removing organic carbon from wastes should be identified. One of these wastes is represented by construction and demolition fines. In this paper, we investigate the use of water in separating the waste by density, to verify the suitability of this method in the separation of carbon-containing materials, both in lab and field scale tests. The results obtained show that half of the carbon (measured as volatile solids) can be separated. However, this method fails to reliably produce a sink fraction suitable for landfilling, as it continues to be characterized by an excessively high organic material content.
\end{abstract}

\section{INTRODUCTION}

Worldwide, landfilling continues to represent the main means of disposing of waste. In the EU, landfilling is the most commonly applied waste treatment method, with over one billion tons, or $48 \%$ of all waste, being landfilled in 2012 (Eurostat 2016). With the aim of reducing the amounts of waste forwarded to landfills, as well as minimizing landfill gas and leachate emissions - legislation in Europe and developed countries has created a situation in which waste with a higher than marginal organic content is being diverted from landfills towards thermal, biological and other treatment systems. As a consequence, the environmental impact and costs of treating large waste streams has risen sharply, particularly due to the presence of waste streams with properties that fit neither of the treatment systems. Construction and demolition waste (CDW) fines are an example of this type of waste. Construction and demolition waste is the largest waste stream in the EU, including mining and quarrying wastes, accounting for $33 \%$ of all waste produced (Eurostat 2016), with fines constituting a major portion of the CDW (Jang, Townsend 2001). Huang et al. (2002) reported fines $<40 \mathrm{~mm}$ as representing $52 \%$ of CDW, and Montero et al. (2010) reported $37.5 \%$ as fines $<8$ $\mathrm{mm}$. CDW fines from Nordic construction and demolition sites typically contain significant amounts of wood since houses in this region are frequently based on timber structures. This makes the waste heterogeneous in its physical properties (particle size, density etc.), rendering conventional mechanical separation complex and expensive. In previous CDW studies conducted in Japan (Montero et al. 2010), the feasibility of wet density-based separation of organic matter has been demonstrated, although a variety of separation steps implying an increasing complexity and higher costs was used. Di Maria et al. (2013) investigated the use of soil washing equipment for use in the wet separation of residual municipal solid waste (MSW) fines. However, the organic waste fraction was removed and not considered. Fines from an MSW landfill were treated in a wet jigger (Wanka et al. 2017), however, fines $<10 \mathrm{~mm}$ were not studied. Float-sink devices are available in many countries, including the UK (Haith recycling group), Germany (Beyer), US (Hosokawa polymer systems) and Sweden (Norditek, since 2nd half of 2017). In this study, a residual CDW fine fraction $(<40 \mathrm{~mm})$ was characterized with the aim of investigating a new treatment method. Float-sink separation was investigated, both in lab and field scale to verify whether this method was suitable as a single method for use in the separation of carbon-containing materials from CDW fines. The resulting sink and float fractions were then characterized to check their suitability for landfilling or incineration, respectively, without further treatment.

\section{MATERIALS AND METHODS}

\subsection{Waste origin}

A Swedish waste management company site provided unsorted CDW crushed using a Komptech Terminator 5000 crusher and sieved using two Komptech Nemus 2700 with $40 \mathrm{~mm}$ drum sieves. The resulting fine fraction contained a 
heterogenous mixture of wood, stones, mineral wool, plastics etc. (Figure 1), which was analyzed in both lab and field scale tests.

\subsection{Sink float lab scale}

From the waste processing site in the south of Sweden, three 60 -liter samples were taken on 3 different days at intervals of approx.10 days in early 2016. In the lab, subsamples were taken using a method similar to that recommended in the Swedish waste association guidelines for waste analysis (Avfall Sverige 2013); an elongated loaf was formed by pouring the waste onto a long strip of construction plastic, and straight segments were taken randomly from across the loaf.

$2000 \mathrm{~g}$ samples (wet weight) were obtained and added to 60 liters of water in a 90 -liter plastic tub similar to a waste bin. The mixture was stirred vigorously and left to settle for 5 minutes. The floating parts were manually removed and put into a 200 and 250 micrometer sieve to let the water drain back. The settled parts were left in the water for the next addition. A second $2000 \mathrm{~g}$ sample was then taken from the loaf, added to the same water, and so on. This was repeated 10 times. For the first of the three samples, this was repeated 11 times with the last using $4600 \mathrm{~g}$ of waste. The floating particles were put into an oven to dry at $70^{\circ} \mathrm{C}$ after each addition of waste. The sunk particles were left in the water for the next addition. Once all the waste had been sink-floated, the process water was removed using a 68-micrometer sieve. The settled materials were put into metal buckets and dried at $70^{\circ} \mathrm{C}$ for several days until dry.

\subsubsection{Sink float field scale waste and sampling}

Twenty cubic meters of waste was transported from the processing facility to a test site in the north of Sweden in the spring of 2017. From this pile, waste samples were initially taken using a front loader tractor, which was weighed at the plant vehicle scale, with an accuracy of \pm $20 \mathrm{~kg}$.

The resulting float and sink fractions were weighed using the same procedure. Fractions were sampled using the "loaf method" described above, by using the tractor to form an elongated string of approx.10 meters, and then obtaining three random samples.

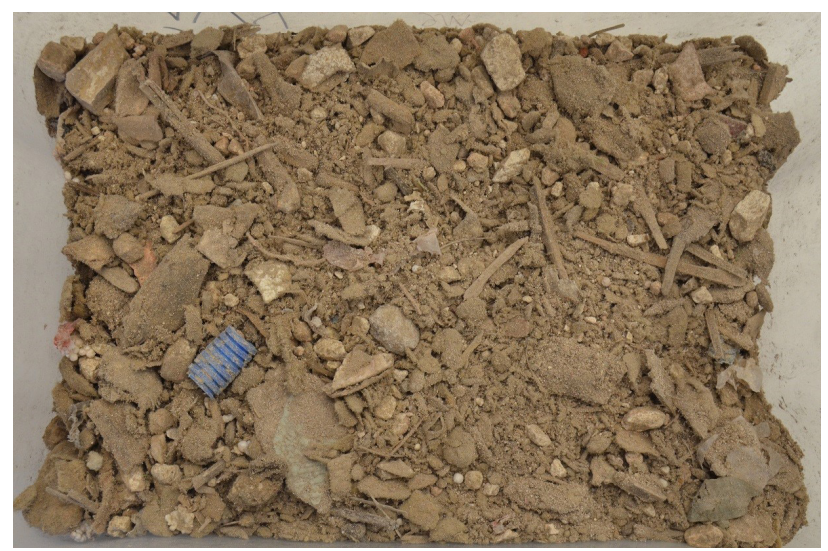

FIGURE 1: Example of CDW fines $<40 \mathrm{~mm}$.

\subsubsection{Experimental setup and procedure}

In order to investigate the validity of the results from the lab scale test for use in a large-scale process, a batch field scale experiment was set up.

An open $20-\mathrm{m}^{3}$ bulk waste container was filled with 10 m3 water and used for density separation. Using a front loader, 2.5 tons of waste were dumped into the container and stirred with the tractor using the bucket scraping from the bottom. Subsequently, the floating particles were mechanically removed by the tractor, letting the water run off towards the side of the container. The final pieces were removed using a hand net. The water was pumped into a GT $500 \mathrm{D}, 1000 / 0500$ geotube, to which a flocculation agent, BASF ZETAG 8140, was added at 20 grams per $\mathrm{m}^{3}$ to prevent clogging of the pores. Following removal of the water using a 2 -inch heavy duty sludge pump, the settled particles were excavated using an excavator.

This process was repeated three times, although for the last two replicates the waste amount was changed to 1.25 tons due to the thickness of the floating material, corresponding to approx. $30 \mathrm{~cm}$ in $67 \mathrm{~cm}$ water, to prevent mixing of the float and sink fractions.

\subsection{Characterization assays}

Samples from the lab scale float and sink fractions were taken using a riffler and milled using cryogenic milling and/or a ring mill at an external laboratory (ALS Scandinavia, Luleå, Sweden). The untreated material and materials from the field scale tests were milled using a Blendtech xpress mixer to particle size $<10 \mathrm{~mm}$ using the sample preparation method described in the EN 12457-4 leaching test standard.

Total solids (TS) and volatile solids (VS) of the milled samples were analyzed by first drying the samples for 24 hours at $105^{\circ} \mathrm{C}$ and then igniting them for 2 hours at $550^{\circ} \mathrm{C}$ according to Swedish standard SS 028113 . TS was calculated by dividing the dry weight of the sample by the wet weight of the sample. VS was calculated by dividing the loss on ignition by the TS. Total organic carbon (TOC) was analyzed using a Shimadzu TOC-V SSM3 Total Organic Carbon Analyzer. The organic content of the sample was measured using the direct method, as described in the European standard EN 13137. Total carbon (TC) was analyzed by measuring the formed $\mathrm{CO}_{2}$ after oxidation in oxygen at $900^{\circ} \mathrm{C}$. TOC was measured in the same way, first removing carbonates through addition of $\mathrm{HCl}$. These measurements were repeated five times. An analysis of the elemental, inorganic and organic carbon was performed by means of a Netch STA409 thermoanalyser using simultaneous Thermogravimetric analysis (TGA) and quadrupole mass spectrometer (QMS). Dried and milled material was used with a sample weight of $134.8 \pm 2.31 \mathrm{mg}$. The heating rate used was $10^{\circ} \mathrm{C} \mathrm{min}{ }^{-1}$, starting from room temperature up to $1000^{\circ} \mathrm{C}$ in argon and air atmospheres. The gas flow was $100 \mathrm{ml} \mathrm{min}^{-1}$. Elemental carbon content was calculated according to (Kumpiene, Robinson et al. 2011) using GNU Octave v. 4.2.1 to calculate the integrals.

Leaching of metals and metalloids was carried out in a one-step batch leaching test at L/S (liquid/solid ratio) 10 
and performed according to European standard EN 124574. Water samples were analyzed using ICP-AES or ICPSFMS for all elements with the exception of fluoride, which was analyzed according to ISO 10304-1. Sulfates (SO4) and chlorides were analyzed in the process water following final float separation. The biomethane potential (BMP), also known as GB21, was analyzed according to Chen et al. (1995) using a 3:1 waste/inoculum on a VS basis as adopted from Owen et al. (1979).

The respiration activity of the sink fraction was analyzed at an external university using a Sapromat respirometer (Comp. Voith, Germany) at $20^{\circ} \mathrm{C}$. Large residues $>10 \mathrm{~mm}$,including metal objects, stones, and glass, was sorted before analysis. Samples were taken using a riffler and watered to $70 \%$ of the water holding capacity (WHC) before analysis.

Elemental analysis was performed using a Thermo Scientific Niton XL3t XRF analyzer. The milled samples were placed in $100 \mathrm{ml}$ LDPE plastic bags and sampled 3 times on each side at non-overlapping spots.

The calorific value was determined for the milled samples using an IKA c200 bomb calorimeter, using no support fuel, and oxygen at 30 bars of pressure.

The water holding capacity was measured in a similar way to that described by Bergman (1996), placing 1 liter of the saturated waste in plastic cylinders on geotextile, covering the top with plastic, letting the water run off for 2 hours, and then measuring the weight and comparing it to the dry mass.

Chlorides and sulfates were analyzed spectrophotometrically (AACE Quaatro, Bran + Luebbe, Germany).

All analyses were carried out in triplicate, at least. Unless otherwise specified, results are presented as "average value" \pm "standard deviation".

\section{RESULTS AND DISCUSSION}

Characteristics of the raw waste are shown in Table 1. A factor 3 variation of VS was observed, clearly showing the heterogenous nature of this material. This is also reflected in the mass balance for the float-sink procedure shown in Figure 2, where 2.8 times more material floats in the field scale tests. This underlines the need for a robust treatment method.

Mass balances for TS, VS and TOC are shown in Figure 2.

\subsection{Characterization of sink fraction in lab scale} tests

\subsubsection{Biological activity}

The carbon content of the sink fraction (Table 2 ) is too high $(>6 \%)$ for landfilling as non-hazardous waste according to Swedish regulations. However, as shown by RA4 and GB21 analysis (Table 2), biological activity is low. Ger-

TABLE 1: Characteristics of the waste used in the two experiments

\begin{tabular}{l|cccc} 
& Unit & Lab scale & Field scale \\
\hline Total solids (TS) & \% of wet weight & $73 \pm 3$ & $75 \pm 2$ \\
\hdashline Volatile solids (VS) & \% of TS & $14 \pm 4$ & $42 \pm 4$ \\
\hline
\end{tabular}

Distribution of Mass, VS and TOC

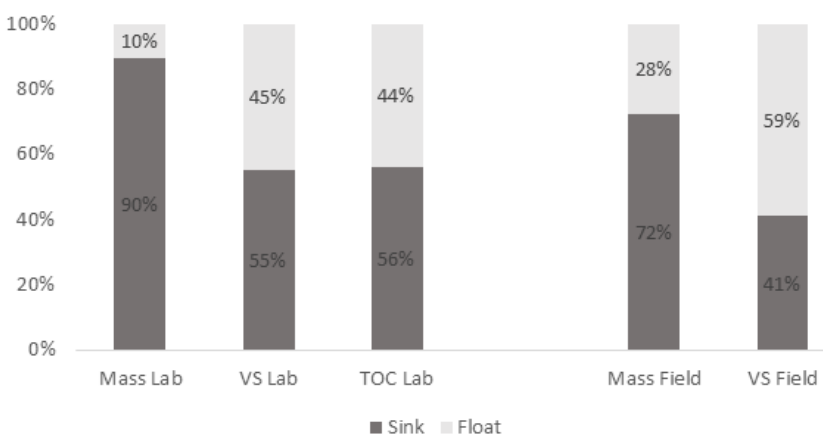

FIGURE 2: Distribution overview of lab and field scale sink-float separation tests. Average values shown, $n=3$.

man regulations for landfilling of mechanically-biologically treated wastes establish a limit for RA4 of $5 \mathrm{mg} \mathrm{O}_{2} \mathrm{~g} \mathrm{TS}^{-1}$, more than 10 times the observed value of this waste. GB21 displays a gas potential approx. 20 times lower than the German limit for mechanically-biologically treated wastes of $20 \mathrm{ml} / \mathrm{g}$ TS. TGA measurements (Table 2) also show that a significant part of the carbon is elemental or inorganic; $18 \% \pm 1 \%$ of the total carbon is organic carbon, $73 \% \pm 8 \%$ elemental and $10 \% \pm 7 \%$ is inorganic carbon. This means that the biological activity of this waste is overestimated when using only TOC or LOI analysis, as discussed in earlier studies (Kumpiene et al. 2011), and as supported by RA4 and GB21 analysis.

\subsubsection{Leaching test}

As shown in Figure 3, leaching from this material is low. Based on the Swedish regulation for landfilling, the majority of metals leach less than the limits for inert waste. The exceptions to this are antimony and fluoride. Antimony is used in paint, glass and ceramics (Weast 1982), and has been shown to leach from CDW in previous studies (Butera et al. 2014). Fluoride leaching is $14 \mathrm{mg} / \mathrm{kg}$ TS with a stan-

TABLE 2: Characterization data for the sink fraction of the lab scale tests.

\begin{tabular}{|c|c|c|}
\hline & Unit & Value \\
\hline VS & $\%$ of TS & $10 \pm 2$ \\
\hline TOC & $\%$ of TS & $6.1 \pm 1.4$ \\
\hline WHC & g water/g TS & $80 \pm 10$ \\
\hline RA4 & $\mathrm{mg} \mathrm{O}_{2} / \mathrm{g} \mathrm{TS}$ & $0.4 \pm 0.09$ \\
\hline GB21 & $\mathrm{ml} \mathrm{gas/g} \mathrm{TS}$ & $1.0 \pm 0.7$ \\
\hline As & $\mathrm{mg} / \mathrm{kg} \mathrm{TS}$ & 18.6 (17/18 measurements <LOD) \\
\hline $\mathrm{Pb}$ & $\mathrm{mg} / \mathrm{kg} \mathrm{TS}$ & $51 \pm 18$ \\
\hline $\mathrm{Cd}$ & $\mathrm{mg} / \mathrm{kg} \mathrm{TS}$ & $<15($ LOD $)$ \\
\hline $\mathrm{Cu}$ & $\mathrm{mg} / \mathrm{kg} \mathrm{TS}$ & $42 \pm 6$ \\
\hline $\mathrm{Cr}$ & $\mathrm{mg} / \mathrm{kg} \mathrm{TS}$ & $86 \pm 18$ \\
\hline $\mathrm{Hg}$ & $\mathrm{mg} / \mathrm{kg} \mathrm{TS}$ & $<15$ (LOD) \\
\hline $\mathrm{Ni}$ & $\mathrm{mg} / \mathrm{kg} \mathrm{TS}$ & $76 \pm 4$ \\
\hline $\mathrm{Zn}$ & $\mathrm{mg} / \mathrm{kg} \mathrm{TS}$ & $345 \pm 109$ \\
\hline
\end{tabular}




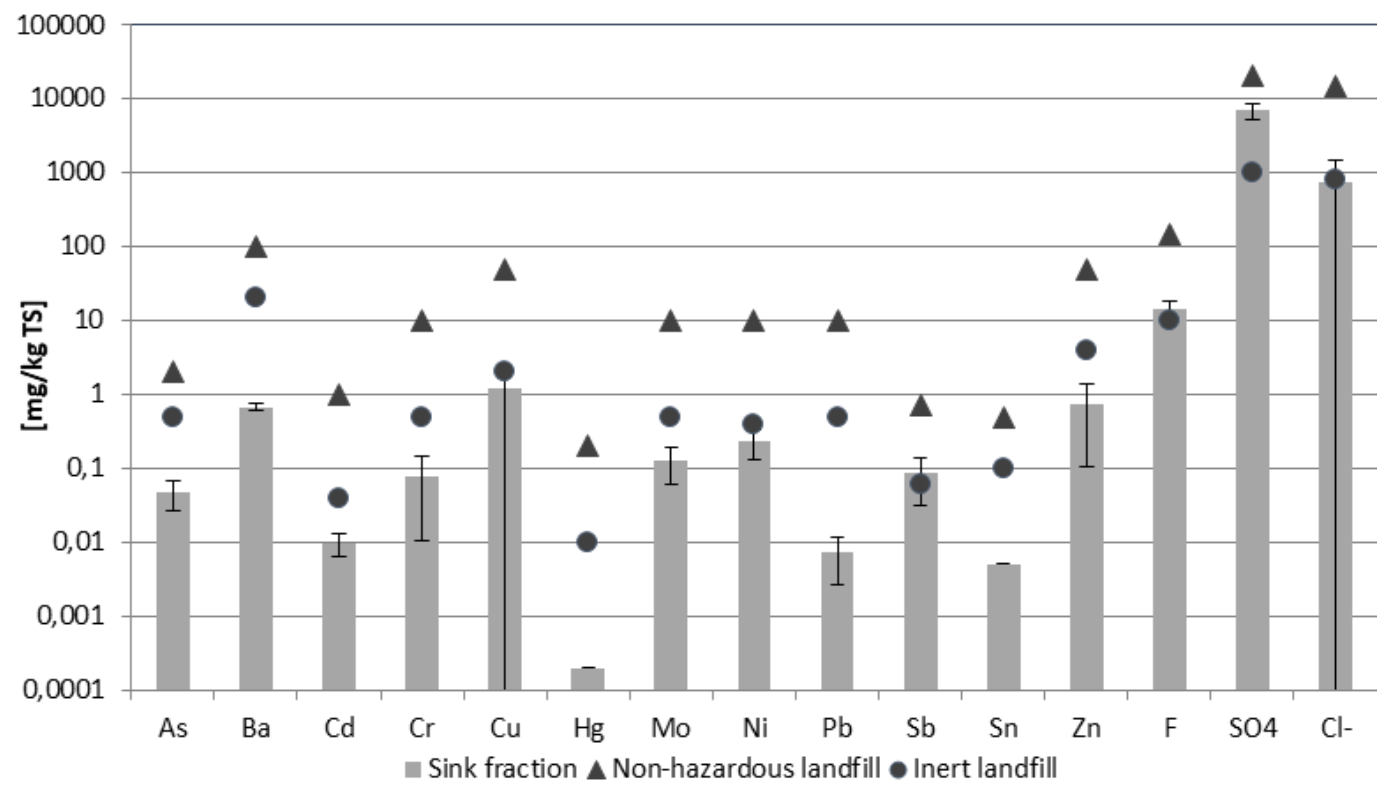

FIGURE 3: Leaching of sink fraction, $n=9$.

dard deviation of $3.8 \mathrm{mg} / \mathrm{kg}$ TS, which is close to the legal limit for landfilling of non-hazardous wastes of $10 \mathrm{mg} /$ kg TS (NFS 2004a); a result similar to other studies (Saca et al. 2017). As for Sulfates and chlorides, these are measured in the process water after all the waste has been added, meaning that leaching of these compounds from the sink fraction will likely be lower, as the waste has already been washed in the float-sink process.

\subsubsection{Landfilling of the sink fraction}

In Sweden, landfilling is regulated by law NFS 2004a and subsequent amendments. Organic carbon is measured as TOC and determined using (EN 13137 2001). The established limits in Sweden are 3\%, 5\% and 6\% for inert, non-hazardous and hazardous wastes, respectively. Some exceptions are provided for, thus allowing homogenous wastes with less than $10 \%$ TOC to be landfilled (NFS 2004b).

In lab scale tests, the sink fraction was shown to have a TOC of $6 \%$. If this waste could be considered as homogenous, it would be suitable for landfilling as provided for by the exception rules mentioned above. However, field scale experiments showed a VS content of $25 \%$ in the sink-fraction, which, in line with the VS/TOC ratio of lab scale tests, would imply a TOC of $15 \%$, thus not suitable for landfilling. However, in other EU countries, such as Germany and Austria, other means may be applied to assess whether a waste features an appropriate organic carbon content for landfilling. Germany has established limits for respiration activity for wastes treated by mechanical-biological processes (Abfallablagerungsverordnung 2001) of $5 \mathrm{mg} \mathrm{O}_{2} \mathrm{~g}^{-1}$, for which the sink fraction from the abovementioned lab scale tests yielded values as illustrated in the table below. Assuming the same VS/RA4 ratio as in the lab scale test, this would provide an RA4 value for the field test of $1 \mathrm{mg}$ $\mathrm{O}_{2} / \mathrm{g}$ TS, still well within the German limit for landfilling.

As shown in Table 4 and Table 5, both the sink and float fraction absorbed significant amounts of water corresponding to three- and two-fold the dry weight, respectively. Accordingly, it would be necessary to dry the material following separation to avoid the landfilling of excessive amounts of water.

Due to the considerably wide variability between the different tests, this method cannot be considered adequate for reliably producing a sink fraction suitable for landfilling in Sweden.

\subsection{Characterization of the float fraction in lab scale}

Ocular characterization shows a high content of wood and organics in the float fraction, which is consistent with the VS of $69 \%$ (Table 3). For incineration, typically a VS content of 20\% (Williams 2005) and 25\% (Hulgaard, Vehlow

TABLE 3: Basic characteristics of the float fraction in the lab scale test.

\begin{tabular}{|c|c|c|}
\hline & Unit & Value \\
\hline VS & $\%$ of TS & $69 \pm 8$ \\
\hline Ash & $\%$ of TS & $31 \pm 8$ \\
\hline TOC & $\%$ of TS & $42 \pm 3$ \\
\hline $\mathrm{HHV}$ & $\mathrm{kJ} / \mathrm{g}$ TS & $14.2 \pm 1.38$ \\
\hline As & $\mathrm{mg} / \mathrm{kg} \mathrm{TS}$ & $17 \pm 7$ \\
\hline $\mathrm{Pb}$ & $\mathrm{mg} / \mathrm{kg} \mathrm{TS}$ & $20 \pm 8$ \\
\hline $\mathrm{Cd}$ & $\mathrm{mg} / \mathrm{kg} \mathrm{TS}$ & $<10$ (LOD) \\
\hline $\mathrm{Cu}$ & $\mathrm{mg} / \mathrm{kg} \mathrm{TS}$ & $53 \pm 14$ \\
\hline $\mathrm{Cr}$ & $\mathrm{mg} / \mathrm{kg} \mathrm{TS}$ & $130 \pm 34$ \\
\hline $\mathrm{Hg}$ & $\mathrm{mg} / \mathrm{kg} \mathrm{TS}$ & $<11$ (LOD) \\
\hline $\mathrm{Ni}$ & $\mathrm{mg} / \mathrm{kg}$ TS & $<61$ (LOD) \\
\hline $\mathrm{Zn}$ & $\mathrm{mg} / \mathrm{kg} \mathrm{TS}$ & $215 \pm 39$ \\
\hline $\mathrm{Ca}$ & $\mathrm{g} / \mathrm{kg}$ TS & $69 \pm 20$ \\
\hline$S$ & $\mathrm{~g} / \mathrm{kg}$ TS & $13 \pm 6$ \\
\hline
\end{tabular}


2010) of wet weight is needed for a waste to be incinerated without using support fuel. Given that the VS to ash ratio is $2: 1$, the float fraction from the lab scale tests will be combustible at any moisture content below $70 \%$. As shown in Table 4 and Table 5, after the sink-float separation the float fraction had a moisture content of approx. $50 \%$, meaning there is no need for drying of the float material after separation.

The heating value of the float fraction was found to be $14.2 \pm 1.38 \mathrm{MJ} \mathrm{kg} \mathrm{TS}^{-1}$ (Table 3). Given a 75\% TS content, this gives a heating value equal to or above that of municipal household waste of 9-13 MJ/kg (Williams 2005, Avfall Sverige 2014).

The sulphur content is high, $13 \mathrm{~g} \mathrm{~kg}^{-1} \mathrm{TS}$, likely from gypsum $\mathrm{CaSO}_{4} 2 \mathrm{H}_{2} \mathrm{O}$, as the waste also contains $\mathrm{Ca}$. Typically, waste forwarded to waste incineration contains approx. $2 \mathrm{~g}$ $\mathrm{kg}^{-1}$ TS of sulphur (Williams 2005, Hulgaard, Vehlow 2010). Higher levels might cause problems with corrosion and $\mathrm{SO}_{2}$ emissions. However, when incinerating alkali and silicate rich wastes such as industrial or municipal solid wastes (MSW), an addition of $\mathrm{CaO}$ and $\mathrm{SO}_{\mathrm{x}}$ may help to reduce ash related problems and corrosion (Skoglund et al. 2016). As the majority of MSW incinerators are equipped with filters to reduce $\mathrm{SO}_{2}$ emissions this fraction may be suitable for co-combustion with MSW.

\subsection{Field scale experiments}

1.25 to 2.5 tons of waste was subjected to sink/float separation. The outputs of the process are shown in Table 4 and Table 5. A considerable difference (up to $30 \%$ ) was observed in the TS entering and exiting the process, likely due to sampling difficulties with the sink fraction, due to the high free phase water content, which produces erroneous TS measurements. The floating percentage is based on the TS of the raw waste and float fraction. Volatile solids in the float fraction were found to be $90 \% \pm 2 \%$, and $25 \% \pm$ $7 \%$ in the sink fraction.

In addition, a total of $63.9 \mathrm{~kg}$ of solids were collected in the geotube, originating from the process water. As this amounts to about $20 \mathrm{~kg}$ per batch, this was considered negligible.

TABLE 4: Weights on entry to and exit from the process

\begin{tabular}{c|c:ccc} 
& Raw waste & Float & Sink \\
\hline Unit & $\mathbf{K g}$ & $\mathbf{K g}$ & $\mathbf{K g}$ \\
\hline Batch 1 & 2480 & 1000 & 2660 \\
\hdashline Batch 2 & 1280 & 540 & 1440 \\
\hline Batch 3 & 1220 & 540 & 1460 \\
\hline
\end{tabular}

TABLE 5: Mass balance of the field scale test.

\begin{tabular}{c:cc|c|c|c} 
& $\begin{array}{c}\text { Raw } \\
\text { waste TS }\end{array}$ & Float TS & Sink TS & Floating & $\begin{array}{c}\text { Difference } \\
\text { In/out }\end{array}$ \\
\hdashline Unit & $\mathrm{Kg}$ & $\mathrm{Kg}$ & $\mathrm{Kg}$ & $\%$ & $\%$ \\
\hline Batch 1 & 1850 & 514 & 1127 & $28 \%$ & $11 \%$ \\
\hline Batch 2 & 955 & 252 & 401 & $26 \%$ & $32 \%$ \\
\hline Batch 3 & 910 & 264 & 520 & $29 \%$ & $14 \%$ \\
\hline
\end{tabular}

\subsubsection{Differences between lab and field scale tests}

The difference in VS found in the sink fraction in lab and field scale tests may have been caused by the experimental procedure. In the lab scale, a more rigorous stirring was performed, including stirring of the whole water mass. Further, the wastes were added using different procedures: In the lab scale, waste was added in increments, whilst in the field scale the waste was added all at once and stirred using a machine. Due to the size of the tractor bucket, it is likely that the whole volume may not have been stirred as rigorously.

Another factor contributing to the difference is the variation in waste itself. With almost three times more material floating in the field scale experiment, and three times more VS in the raw waste, it is evident that the waste tested in the field scale trials contained more wood and organic materials. Using the field scale waste in a lab scale test would have likely produced a high VS sink fraction as well, meaning that the results from the field scale test would be in line with those of the lab scale test. This also implies that a lab scale test would have sufficed. Since the field scale test was carried out as a batch experiment without any special sink-float machinery, no extra information was provided with regard to practical applications. Any practical applications using sink-float should always be performed using a continuous process, as discussed also by Bilitewski (2010).

\section{CONCLUSIONS}

Density based separation using water was successfully applied to separate an organic material from inorganic. However, the resulting sink fraction may not always be suitable for landfilling, as the organic content may continue to be too high. Nevertheless, the use of analytical assays other than TOC to measure biological activity indicate that the organic content remaining in the sink fraction is not as biologically available as the TOC value may suggest.

In a practical Swedish scenario, sink-float separation fails to reduce the carbon content of the treated material in a reliable manner. In addition, since the material absorbs significant amounts of water, if density is to be used for separation this should be undertaken using a dry method.

\subsection{Further research}

Further research methods to be applied include the use of dry density separation methods, such as wind sifting, and combination treatments also including sieves or screens. Temporal variations of the waste should also be investigated further to better assess the appropriateness and feasibility of treatment methods. It is clear however that temporal variations may be considerable (up to a factor of three), thus a robust treatment method is needed.

\section{ACKNOWLEDGEMENTS}

The authors gratefully thank RGS Nordic (formerly known as RGS90) and MISTRA (Swedish Foundation for strategic environmental research) for the financial sup- 
port, and the staff at RGS Nordic Örnsköldsvik and Göteborg office for helping with the sampling and field tests. We also thank Desirée Nordmark and Maria Gelfgren for helping with analysis in the lab. Thomas Pabst is also acknowledged for being a good lab partner during his master thesis studies at LTU.

\section{REFERENCES}

Abfallablagerungsverordnung., 2001. Verordnung über die umweltverträgliche Ablagerung von Siedlungsabfällen und über biologische Abfallbehandlungsanlagen in der Fassung vom 20.02.2001, 31.01.2001 Bundesgesetzblatt Teil I, Nr. 10, S. 305-324, Bonn, 27.02.2001, Germany. Bonn: .

Avfall Sverige., 2014. Bränslekvalitet Sammansättning och egenskaper för avfallsbränsle till energiåtervinning [Fuel quality, content, and properties of waste fuels for energy recovery] . Rapport E2014:01 ISBN 1103-4092.

Avfall Sverige., 2013. Manual för plockanalys av hushållens kärl- och säckavfall. [Manual for waste analysis of household waste in bins and bags], ISBN 1103-4092.

Bergman, A., 1996. Characterisation of industrial wastes. Licentiate thesis ed. Luleå: Luleå University of Technology ISBN 0280-8242.

Bilitewski, B., 2010. Mechanical Treatment: Unit Processes. In: Solid Waste Technology \& Management, pp. 319-348 SCOPUS. DOI 10.1002/9780470666883.ch24.

Butera, S., Christensen, T.H. And Astrup, T.F., 2014. Composition and leaching of construction and demolition waste: Inorganic elements and organic compounds. Journal of Hazardous Materials, vol. 276, pp. 302-311 SCOPUS. DOI 10.1016/j.jhazmat.2014.05.033.

Chen, H., Ecke, H., Kylefors, K., Bergman, A. And Lagerkvist, A., 1995. Biochemical methane potential (BMP) assays of solid waste samples. Fifth International Landfill Symposium, vol. 1, no. 3, pp. 615627 SCOPUS.

Di Maria, F., A. Sordi, C. Micale, G. Cirulli, M. Marionni and W. Rossi. Urban mining: increasing material recovery from mechanical biological treatment of residual municipal solid wasteAnonymous Fourteenth International Waste Management and Landfill Symposium. S. Margherita di Pula, Italy, 2013.

EN 13 137, 2001. Characterization of Waste-determination of Total Organic Carbon (TOC) in Waste, Sludges and Sediments. CEN, European Standard EN 13 137. Characterization of Waste-Determination of Total Organic Carbon (TOC) in Waste, Sludges and Sediments, European Committee for Standardization, Brussels, Belgium.

Eurostat, 2016. Energy, transport and environment indicators. Energy, Transport and Environment Indicators. Available from: http:// ec.europa.eu/eurostat/en/web/products-statistical-books/-/KSDK-16-001 ISSN 1725-4566.
Huang, W., Lin, D., Chang, N. and Lin, K., 2002. Recycling of construction and demolition waste via a mechanical sorting process. Resources, Conservation and Recycling, vol. 37, no. 1, pp. 23-37.

Hulgaard, T. and Vehlow, J., 2010. Incineration: Process and Technology. In: Solid Waste Technology \& Management, pp. 363-392 SCOPUS. DOI 10.1002/9780470666883.ch26.

Jang, Y.-. and Townsend, T., 2001. Sulfate leaching from recovered construction and demolition debris fines. Advances in Environmental Research, vol. 5, no. 3, pp. 203-217. SCOPUS. DOI 10.1016/S10930191(00)00056-3.

Kumpiene, J., Robinson, R., Brännvall, E., Nordmark, D., Bjurström, H., Andreas, L., Lagerkvist, A. and Ecke, H., 2011. Carbon speciation in ash, residual waste and contaminated soil by thermal and chemical analyses. Waste Management, vol. 31, no. 1, pp. 18-25 SCOPUS. DOI 10.1016/j.wasman.2010.06.011.

Montero, A., Tojo, Y., Matsuo, T., Matsuto, T., Yamada, M., Asakura, H. and Ono, Y., 2010. Gypsum and organic matter distribution in a mixed construction and demolition waste sorting process and their possible removal from outputs. Journal of Hazardous Materials, vol. 175 , no. 1-3, pp. $747-753$ SCOPUS. DOI 10.1016/j. jhazmat.2009.10.072.

NFS., 2004a. Naturvårdsverkets föreskrifter om deponering, kriterier och förfaranden för mottagning av avfall vid anläggningar för deponering av avfall [in Swedish]; Naturvårdsverkets författningssamling 2004:10.

NFS, 2004b. NFS 2004:4 Naturvårdsverkets föreskrifter och allmänna råd om hantering av brännbart avfall och organiskt avfall [in Swedish]. Naturvårdsverkets Författningssamling.

Owen, W.F., Stuckey, D.C., Healy Jr., J.B., Young, L.Y. and Mccarty, P.I., 1979. Bioassay for monitoring biochemical methane potential and anaerobic toxicity. Water Research, vol. 13, no. 6, pp. 485-492 SCOPUS. DOI 10.1016/0043-1354(79)90043-5.

Saca, N., Dimache, A., Radu, L.R. and lancu, I., 2017. Leaching behavior of some demolition wastes. Journal of Material Cycles and Waste Management, vol. 19, no. 2, pp. $623-630$ SCOPUS. DOI 10.1007/ s10163-015-0459-7.

Skoglund, N., Bäfver, L., Fahlström, J., Holmén, E. and Renström, C., 2016. Fuel design in co-combustion of demolition wood chips and municipal sewage sludge. Fuel Processing Technology, vol. 141, pp. 196-201 SCOPUS. DOI 10.1016/j.fuproc.2015.08.037.

Wanka, S., Münnich, K. and Fricke, K., 2017. Landfill Mining - Wet mechanical treatment of fine MSW with a wet jigger. Waste Management, vol. 59, pp. 316-323. SCOPUS. DOI 10.1016/j.wasman.2016.10.050.

Weast, R.C., 1982. CRC Handbook of chemistry and physics: a ready-reference book of chemical and physical data. Ed. 63 (1982-1983). R.C. WEAST ed., Cleveland, Ohio: CRC P. ISBN 0-8493-0463-6.

Williams, P.T., 2005. Waste treatment and disposal. 2. ed. ed. Hoboken, N.J.: J. Wiley \& Sons ISBN 0-470-84913-4 (hft.). 